DOI: https://doi.org/10.31933/dijdbm.v3i1

Received: 29 November 2021, Revised: 21 December 2021, Publish: 1 January 2022

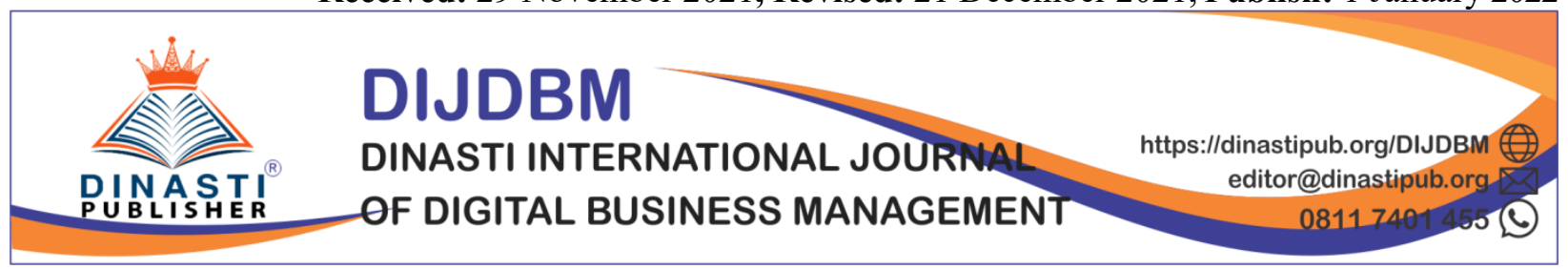

\title{
THE POTENTIAL OF RIBA IN SHARIA GOLD PAWNING
}

Muh Shadiqul Fajri AF ${ }^{1}$, Abdul Hamid Habbe ${ }^{2}$, Abdul Wahab ${ }^{3}$

1) IAIN Parepare, Sulawesi Selatan, Indonesia, fajriisme86@gmail.com

${ }^{2)}$ University of Hasanuddin, Sulawesi Selatan, Indonesia, hamidhabbe@fe.unhas.ac.id

3) UIN Alauddin, Sulawesi Selatan, Indonesia, abdulwahab@uin-alauddin.ac.id

\section{Corresponding Author: Muh Shadiqul Fajri AF}

Abstract: The practice of Islamic gold pawning in Islamic financial institutions that is in demand by many people in Indonesia has the potential to be included in the practice of usury. The practice of usury is meant to occur because of the merger of qardh and ijarah contracts. This is strictly prohibited in the practice of economics in Islam. This article aims as a critique of the DSN-MUI fatwa No. 26 of 2002 concerning Gold Pawning which allows the merging of qardh and ijarah contracts. Basically, the collection of fees on the qardh contract is allowed for costs that are clearly needed and do not become a profit for Islamic financial institutions. This type of research is descriptive-qualitative with a literature study approach with data sources, namely secondary data obtained from previous studies, and other reference sources.

Keywords: Pawn, Gold, Rahn, Riba, Sharia.

\section{INTRODUCTION}

Everyone's needs are always diverse and strongly influenced by material-oriented needs. When people need funds, they use banking services by financing as an alternative way. This can be seen from the development of the financing portfolio in banks which is increasing from time to time. But on the other hand, some people have difficulty in accessing banking services. They are faced with various administrative processes and complicated requirements so that some of them go to moneylenders even though they offer quite high interest rates. For those who have assets that can be used as collateral, pawnshops are the main choice. Pegadaian (Pawning State Company) is a solution for the community when they need funds in an urgent and fast condition.

Historically, the practice of pawning has existed since the reign of the Dutch. After going through a long process, on April 1, 1901, the Dutch East Indies government established the first State Pawnshop in Sukabumi, West Java (Pegadaian, n.d.). The practice of pawning in Islamic 
teachings is a muamalah case. Muamalah is a human relationship in social interaction according to the Shari'a because humans are social beings who cannot live independently. The basic law of muamalah is lawful unless there is evidence that prohibits it.

The birth of the sharia pawn practice in Indonesia (in the form of an institution) is an alternative solution to the conventional pawn practice which includes the practice of usury. The sharia pawn system in sharia pawn institutions does not emphasize the giving of interest on the pawned goods. One of the sharia pawn products that is most in demand by the public is sharia gold pawning. Islamic gold pawning is not only for pawning institutions, but has spread to the services of Islamic Financial Institutions (LKS). Gold for the people of Indonesia is a fairly safe investment choice with a tendency for a stable price value every year.

With the existence of a gold pawn product in Islamic financial institutions, it seems to be the answer to the needs of today's society.With the term "sharia" attached, it makes people more comfortable with the halal guarantee.This is regulated in the fatwa of the MUI National Sharia Council (DSN) No. 26 of 2002 concerning the Rahn (Pawn) of Gold. However, the DSN fatwa created a cross of opinion among Muslim scholars in Indonesia.The fatwa allows for a hybridcontract or a combination of contracts between qardh and ijarah contracts. The qardh contract occurs when the LKS provides loans to customers with gold as collateral, while the ijarah contract occurs when the LKS rents out the gold deposit box (Safe Deposit Box) and collects wages from the ijarah contract. The merging of these contracts contradicts the hadith narrated by Amru bin Shuaib which reads: "It is not lawful to combine a loan agreement and a sale and purchase agreement, it is not lawful to have two conditions in one sale, it is not lawful to profit from goods that are not under your guarantee and it is not lawful to sell goods that are not yours". (Narrated by Abu Dawud)

\section{LITERATURE REVIEW}

\section{Gold Concept in Islam}

Gold has been an investment item for decades. Its value is not affected by inflation and tends to rise every year, making people who like investment look at gold as their object. Moreover, gold maintenance is quite easy and can also be used as jewelry. In addition, gold was also used as a transaction tool long before Islam came. In Islam, gold has been mentioned in several verses of the Qur'an such as in QS Ali Imran (14): "Made beautiful in (the view of) humans the love of what they want, namely: women, children, a lot of wealth. of gold, silver, domesticated horses, livestock and fields. That is the pleasure of living in this world, and with Allah is a good place to return (heaven)." In addition, there is also in the QS at-Taubah (34): "O you who believe, indeed most of the Jewish scholars and Christian monks actually eat people's wealth in a false way and they hinder (people) from the path of Allah. And those who save gold and silver and do not spend them in the way of Allah, then inform them, (that they will have) a painful torment." 
In Islamic studies, gold is included in the type of usury goods. This matter is contained in the Hadith narrated by Muslim which means:If gold is exchanged for gold, silver is exchanged for silver, wheat is exchanged for wheat, sya'ir wheat is exchanged for poetry, dates are exchanged for dates, and salt is exchanged for salt, then the amount (measures or scales) must be the same and paid in cash. Whoever asks for additional, then he has committed usury. The person who takes the addition and the person who gives it are both in sin. "The scholars have agreed that the six commodities (gold, silver, wheat, sya'ir, dates and salt) mentioned in the hadith above are ribawi commodities. So that the six commodities may be traded by barter as long as they meet the requirements (Tausikal, 2009).

Gold can be used as a commodity to store wealth. But not a few people buy gold to make it an investment commodity which tends to contain elements of speculation which is forbidden in Islam. The speculation in question is that if a customer comes to LKS to pawn his gold, then the customer gets a loan worth $80 \%$ of the estimated value of the pawned gold and with that loan he then buys new gold. After getting new gold, he then went to LKS to pawn it as he did the first time and so on until the price of gold rose and then sold it. Speculation is prohibited in Islamic teachings because it contains elements of gharar.

\section{Sharia Gold Pawn Concept}

Linguistically, the word ar-Rahn means eternal and guarantee. Ar-Rahn contract can also be referred to as collateral. According to Taqiyuddin Abu Bakr al-Husaini, al-rahn is al-tsubut which is something that is fixed or al-ihtibas which is holding something back (Husaini, 1994). The concept of ar-Rahn is a means to help each other for Muslims without any compensation for services (Haroen, 2000). As for terminology, ar-rahn is holding one of the borrower's property as collateral for the loan he received, and the item has economic value. Thus, the holding party obtains a guarantee to be able to take back all or part of the receivables (Syafi'i, 2001). From the description above, it can be concluded that the ar-rahn contract is a guarantee of debt, collateral or more popularly known as pawn.

Islamic law explains that the concept of pawn is a liability for debts that are carried out if the debtor fails to fulfill his obligations. Categories of goods that can be used as collateral are all goods that can be traded or have economic value. The collateral can only be sold if within the agreed time the debtor cannot pay off the debt. Therefore, the rights of the creditor are only related to collateral if the debtor is unable to pay off the debt (Haroen, 2000).

The concept of pawning gold is a pawning process that uses gold as collateral for debt. Sharia Gold Pawn is the concept of pawning or handing over assets or valuables in the form of gold from the customer (called ar-rahin) to the lender (called al-murtahin) to be used as collateral (called almarhun) for the provision of money loans (al-marhun) given to the customer (al-marhunbih). Sharia 
gold pawn financing is a financing product where Islamic financial institutions provide loan facilities to customers with collateral in the form of gold by following the principles of sharia pawning, then the gold is placed in the control and maintenance of Islamic financial institutions and for this maintenance Islamic financial institutions charge rental fees on the basis of ijarah principle.

\section{Legal Basis of Pawn}

The fuqaha agree that the pawn contract (rahn) is permissible in Islamic teachings. The legal basis for the practice of pawning is derived from the Qur'an and the Hadith of the Prophet sallallaahu 'alaihi wasallam. The legal basis for pawning (rahn) is stated in the Qur'an surah al-Baqarah verse 283, namely:

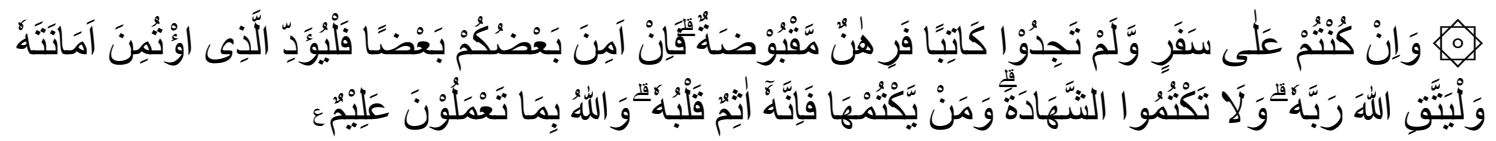

Meaning:

"If you are on a journey (and do mu'amalah not in cash) while you do not find a writer, then there should be collateral held (by the debtor). But if some of you believe in others, then let the one who is trusted fulfill his mandate (debt) and let him fear Allah his Lord; And do not (witnesses) hide your testimony. And whoever hides it, then indeed he is a sinner in his heart; and Allah is Knowing of what you do."

The verse describes the implementation of pawning in debt and credit contracts in a state of shafar (traveling), but the scholars have agreed to allow pawning both on the trip and muqim (residence), as long as the collateral can be directly controlled by law by the lender (Pratiwi, 2016). Not only from the arguments of the Qur'an, the practice of pawning is also explained in the hadith of the Prophet, including: Hadith narrated by Bukhari and Muslim from Aisha Radhiallahu Anha: "Indeed the Messenger of Allah once bought food from a Jew at a certain time, and he made armor as a guarantee to him." This hadith can be used as a reference to show that the practice of pawning occurred during the time of the Prophet. In addition to the legal basis from the Koran and the Hadith of the Prophet, the practice of sharia pawning and specifically sharia gold pawning is supported by the fatwa of scholars from the National Sharia Council (DSN) of the Indonesian Ulama Council (MUI) number 25/DSN-MUI/III/2002 concerning Rahn and fatwa number 26/DSN-MUI/III/2002 regarding Gold Pawning.

\section{Riba in Islam}

The word usury comes from Arabic, etymologically means additional (azziyadah) (Hadi, 1993). Riba in English is referred to as usury which means additional money on capital obtained by practices prohibited by sharia, either with a small additional amount or with a large additional amount. In the terminology of fiqh, usury is a special addition owned by one of the parties involved 
without any particular reward (Sar'an, 2019). Basically, usury is categorized into two types, namely usury on accounts payable and usury of buying and selling. First, Riba due to debts is called Riba Qardh, which is a certain benefit or level of excess required of the debtor (muqtarid), and Riba Jahiliyah, which is debt that is paid from the principal, because the borrower is unable to pay the debt at the stipulated time. Second, Riba due to buying and selling is called Riba Fadl, namely the exchange between similar goods with different levels or doses and the goods exchanged are included in the type of usury goods. And Riba Nasi'ah, namely the suspension of the delivery of the required types of usury goods with other types of usury goods. Riba nasi'ah arises and occurs because of differences, changes, or additions between what is given now and what is given later.

The prohibition of usury in the Qur'an is contained in several verses in the Qur'an, namely in Surah al-Baqarah verses 275-276 and verses 278-279, and Surah Ali Imran verses 130-131. Apart from the verses of the Qur'an, there are also prohibitions on the practice of usury from several hadiths of the Prophet, namely:

- From Abu Hurairah Ra, Rasulullah SAW said which means; "Stay away from the seven mubiqat things (which bring destruction). The companions then asked what are the seven things, O Messenger of Allah? Rasulullah SAW then replied associating partners with Allah, magic, killing souls that Allah has forbidden except for reasons justified by the Shari'a, eating usury, eating orphans' property, running away from the battlefield, hurling accusations of adultery against a good woman who is careless and has faith. "(Narrated by Bukhari and Muslim).

- From Samurah bin Jundab RA, Rasulullah SAW said which means; "One night I saw two men taking me out to the holy land. We walked together until we came to a river of blood. In the river stood a man and in the middle of the river there was a man. There are stones in front of him. Then the man who was in the river tried to get out. Every time he was about to come out of the river, the man threw a bolt into his mouth so that it returned to its original place. Every time he was about to go out, the man threw a stone into his mouth so that he returned to where he was. I asked, what is this? They said, "The man you saw in the river, O Messenger of Allah, is a usurer." (Narrated by Bukhari).

- From Jabir bin Abdilla RA; "The Messenger of Allah (SAW) cursed the eater of usury, the one who gave usury, the writer and the two witnesses. The Messenger of Allah then said they were all the same."(HR Muslim).

From the various explanations of the arguments of the Qur'an and Hadith, it can be concluded that the practice of usury is a forbidden matter and one of the major sins that bring misery to the perpetrator.

\section{The Position of Fatwa in Islamic Law and Civil Law in Indonesia}


Fatwa can be defined as a decision that contains advice, appeals and considerations to the public or the general public issued by individuals, in this case called the mufti, or an institution whose authority has been recognized. The word "fatwa" is mentioned several times in the Koran, namely in Surah Yusuf verse 43 and Surah Shaafaat verse 11. The issuance of a fatwa by a mufti or institution that has the authority is based on a question or request for a religious legal view related to a phenomenon that is currently happening in the middle of the world. Public. Fatwas have an important role in Islamic law. The fatwa is an explanation from the scholars (fuqaha) of the problems that have just been encountered in the community. This happens because the Koran, Hadith, Ijma', and Qiyas, as sources of law, do not explain their legal provisions explicitly. Therefore, the fatwa resulted from a process of ijtihad in elaborating the law in the Qur'an and the Hadith of the Prophet. The discussion of fatwas is closely related to the discussion of the existence of ijtihad. Ijtihad in terms is to mobilize all abilities in terms of knowledge by a fuqaha (fiqh expert) in producing dzanni syar'i law (Sarwat, 2015).

The fatwa begins at the end of the apostolic period. However, the presence of the Companions (Sahabah), tabi'in and tabiut-tabiin facilitated every problem of Islamic law encountered by the people at that time. In the era of the Ottoman dynasty, a special institution was established that had the authority to issue fatwas. The institution is an official state institution whose emir is called Sheikh al-Islam who also serves as the mufti of the kingdom. The previous (classical) fatwas were more individual in nature, made within the scope of certain schools of jurisprudence. Meanwhile, contemporary fatwas are more institutional and cross-mazhab in character or there is a mix between schools so that the results of the decision are collective ijtihad. Collective ijtihad cannot be equated with ijma' because in the process of collective ijtihad it does not represent all scholars which is a condition for the occurrence of ijma'.

The process of collective ijtihad is possible several times with different actors even at different times and places so that it tends to produce different legal findings with the discussion of the same problem. While ijma' is a decision in which there is no room for difference of opinion because it has been agreed upon by all scholars. From these two differences, it can be concluded that a fatwa which is the result of collective ijtihad is not an ijma' that allows the public to accept or not accept the result of a fatwa. While ijma' is a decision in which there is no room for difference of opinion because it has been agreed upon by all scholars. From these two differences, it can be concluded that a fatwa which is the result of collective ijtihad is not an ijma' that allows the public to accept or not accept the result of a fatwa. While ijma' is a decision in which there is no room for difference of opinion because it has been agreed upon by all scholars. From these two differences, it can be concluded that a fatwa which is the result of collective ijtihad is not an ijma' that allows the public to accept or not accept the result of a fatwa. 
In Indonesia, the official state institution that has the authority to issue fatwas is the Indonesian Ulema Council (MUI). The MUI fatwa is divided into three categories. First, the fatwa based on the general public's request. One example of this fatwa category is fatwa number 56 of 2016 concerning the law using non-Muslim religious attributes. Second, fatwas are issued based on requests from ministries or other state institutions. One example of this fatwa is fatwa number 4 of 2005 concerning abortion and also fatwa number 16 of 2005 on the use of a special polio vaccine. Third, the fatwa issued based on the issuance of legislation so that this fatwa is bound in positive law. Fatwas in this category are fatwas on halal status and also fatwas on basic principles of Islamic banking which are further regulated by the Financial Services Authority (OJK) and Bank Indonesia (Purnama, 2017). Therefore, all operational activities of Islamic financial institutions must follow the regulations that have been decreed by the MUI.

To realize the aspirations of Muslims in the economic field and to respond to the issues that occurred, in 1999 the MUI established the National Sharia Council (DSN). DSN has the authority to issue fatwas related to products and all operations of Islamic financial institutions in Indonesia. The fatwa is binding and has a permanent legal basis which has been regulated in Law Number 21 of 2008.

\section{RESEARCH METHODS}

This research is a type of literature study by looking for theoretical references that are relevant to the cases or problems found. The theoretical reference obtained by means of literature study research and then used as the basic foundation and main tool for analyzing data. Research with literature studies does not have to go to the field and meet with respondents. The data needed in the research can be obtained from library sources or documents. This study tries to explain the potential for the practice of usury in the sharia gold pawn system in Indonesia. The type of data used by the author in this study is secondary data obtained from journals, books, documentation and the internet. The data that has been obtained is then analyzed using a qualitative descriptive analysis method. Researchers analyzed the data using the triangulation method. Triangulation is essentially a multi-method approach that researchers use when collecting and analyzing data. The basic idea is that the phenomenon under study can be well understood so that a high level of truth can be obtained when approached from various points of view. Photographing a single phenomenon from different points of view will allow a reliable degree of truth to be obtained. Therefore, triangulation is an attempt to check the truth of data or information obtained by researchers from various different points of view by reducing as much as possible the bias that occurs during data collection and analysis.

\section{FINDINGS AND DISCUSSION}

In general, the practice of pawning gold in Indonesia uses three contracts, namely the rahn contract for pawning, the al-qardh contract for loans, and the ijarah contract for the Safe Deposit 
Box (SDB) rental process. In the DSN-MUI fatwa No. 26 of 2002 concerning Gold Pawning stipulates that the cost of storing goods (marhun) comes from the customer/pawner (rahin), where the amount is based on real costs. From this sentence, we can conclude that the fees or costs for storing the pawn may not result in additional profits for Islamic Financial Institutions (LKS), because only the costs that are clearly needed are charged to the customer/pawner (rahin).

In the implementation of the gold pawning by LKS in Indonesia, several anomalies were found in the practice of the golden Rahn. First, there is a merger between the Qard contract and the Ijarah contract. The combination of these two contracts is forbidden because it is in accordance with the prohibition in the hadith of the Prophet. The combination of the Qard contract which is a loan contract, which cannot get additional or excess or benefits from the loan combined with the Ijarah contract which is a service sale and purchase contract that clearly imposes ujroh for the customer. In the DSN-MUI fatwa No. 26 it is stated that the costs incurred are only costs that are clearly needed, this could be a trick or a distraction from the practice of usury or a middle way of merging this prohibited contract.

Second, ijarah contracts that are practiced in Islamic banking are proven to benefit from this contract, beyond the real costs required. Is it true that Islamic Financial Institutions do not profit from the rental of Safe Deposit Box (SDB)? What happened in the qard contract was that the gold pawning was combined with the gold pawn rental for security that LKS charged fees that varied from Rp. 225,000 to Rp.750,000 per year for pawn gold weighing 25 grams. Even though it costs that much to rent SDB ranging from small to large ones that can accommodate hundreds of 25 grams gold bars. And even more surprising, when the same customer pawned his gold for the second time, he was again charged a fee equal to the cost of renting an SDB, even though the SDB he paid in the first pledge was still able to accommodate hundreds of 25 grams bars of gold.

The ujroh calculation system determined by LKS based on the number of days varies, some are wearing ujroh per day, some are per ten days, some are every five days, some are per month. It is recommended that the application of ujrah is calculated per day. If it is calculated per fifteen days, LKS has the potential to take more profit than the remaining days from the due date for paying off the mortgage. The amount of ujrah calculation should not be related to the amount of the loan. From this it is also seen that LKS take advantage of the benefits, not only costs that are clearly needed or real costs.

Third, LKS seems to be competing in making loans using Rahn gold. This was very evident before $\mathrm{BI}$ issued a regulation regarding restrictions on gold pawning in Islamic banks. After that, BI limited the portion of Islamic gold pawning in Islamic banks to a maximum of $10 \%$ of total financing. Qard funds are funds that do not provide additional value or fees for sharia children. Qard is one of the social instruments of Islamic banks, whose funds come from the capital portion 
of the LKS, the profits of the LKS set aside and other institutions or individuals who entrust the distribution of their infaq to the LKS. In addition to the fact that qard funds do not provide material business benefits to Islamic banks, gold pawning also carries a high risk, especially due to fluctuating gold prices.

Hybrid contracts or amalgamation of contracts is a controversial issue in the field of Islamic finance because of the hadith that prohibits "two contracts (akad) in one transaction". Misinterpretation of the hadith has the potential to justify any attempt to allow hybrid contracts to occur in the field of Islamic finance regardless of the view that it will hinder product development in Islamic banking. However, in the view of Islamic sharia a transaction can consist of more than one contract and it is halal, the combination must follow Sharia guidelines and parameters.

Ibn Qayyim argues that the prohibition of hybrid contracts between sale and purchase contracts and loans (qardh), even though each contract stands individually or separately. The prohibition against combining qardh (loan) and sales contracts is to avoid the practice of usury. The majority of Muslim scholars agree to prohibit the combination of sales and loan contracts in one transaction. For example, a violation of sharia law is when disbursing loan facilities for Islamic banks and at the same time the customer sells certain assets to Islamic banks. This transaction falls under the category of combining a loan contract with a sale for a profit.

The DSN fatwa number 26/DSN-MUI/III/2002 concerning the Golden Rahn contains 4 points, namely: (1) Golden Rahn is allowed based on the Rahn principle. (2) The cost and cost of storing goods (marhun) is borne by the pawnbroker (rahin). (3) The cost as referred to in paragraph 2 is based on expenses that are actually needed. (4) The cost of storing goods (marhun) is carried out based on an Ijarah contract. The DSN fatwa allows the merging of two contracts, namely the Qardh contract and the Ijarah contract. Qardh contracts occur when LKS provides loans to customers with gold collateral, while ijarah contracts occur when LKS rents out a Safe Deposit Box and collects wages from the ijarah contract. The amalgamation of the contract contradicts the hadith of the Prophet narrated by Amru bin Shuaib which reads: "It is not lawful to combine a loan contract and a sale and purchase agreement, It is not lawful to have two conditions in one sale and purchase, it is not lawful to profit from goods that are not under your guarantee, and it is not lawful to sell goods that do not belong to you." (Narrated by Abu Dawud). The thing to remember is that the ijarah contract is part of the sale and purchase contract, because essentially ijarah is the sale and purchase of services. So combining a qardh contract and an ijarah contract is forbidden.

Collecting fees from customers for storage fees in the amount of costs that are clearly needed is halal (point 3 of DSN fatwa number 26 of 2002). On the condition that LKS cannot take profits or profits to be included in the LKS cash record and the consequences of paying storage fees require LKS to guarantee the pawned gold if something unexpected happens. Taking 
this fee is allowed because LKS does not make a profit from this transaction and this merger is not intended to make the creditor profit from the loan. On the other hand, this merger does not harm the LKS who have done good in providing interest-free loans (Tarmizi, 2017).

In fact, LKS makes a lot of profit from the cost of storing the mortgaged gold, not just the storage costs that are actually needed. Therefore, it is not surprising that several LKS are competing to provide gold pawn financing considering the large income for LKS from the cost of storing pawned gold.

\section{CONCLUSION}

The practice of Islamic gold pawning in Islamic financial institutions that is of interest to many people in Indonesia has the potential to be included in the practice of usury, namely the merging of qardh (loan) contracts and ijarah contracts (selling services). This is clearly prohibited by the Prophet in his saying which reads: "It is not lawful to combine a loan agreement and a sale and purchase, it is not lawful to have two conditions in one sale, it is not lawful to profit from goods that are not under your guarantee and it is not lawful to sell goods that do not belong to you." (Narrated by Abu Dawud). In practice, LKS made a profit in financing the gold pawn and did not apply the DSN fatwa regarding Gold Pawning points 2 and 3 of the fatwa. This will certainly have a negative impact on the public's view of Islamic Financial Institutions and will have an impact on national economic stability.

\section{BIBLIOGRAPHY}

Hadi, A. S. A. (1993). Bunga Bank dalam Islam (M. Thalib (ed.)). Al-Ikhlas.

Haroen, N. (2000). Fiqih Muamalah (Cet. 1). Gaya Media Pratama.

Husaini, T. A. B. (1994). Kifatat al-Akhyar fí Hall al-Ikhtishar. Dar al-Khair.

Pegadaian. (n.d.). Sejarah Pegadaian. Retrieved December 28, 2021, from https://www.pegadaian.co.id/profil/sejarah-perusahaan

Pratiwi, N. (2016). Penerapan Pembiayaan Gadai Emas di BRI Syariah. Al-Masraf: Jurnal Lembaga Keuangan Dan Perbankan, 1, 1-12.

Purnama, D. (2017). MUI Kenalkan Berbagai Jenis Fatwa. https://nasional.okezone.com/read/2017/01/17/337/1593632/mui-kenalkan-berbagai-jenisfatwa

Sar'an. (2019). Riba dalam Perspektif Sejarah dan Islam. At-Tasyri'iy: Jurnal Prodi Perbankan Syariah, 1, 81-93.

Sarwat, A. (2015). Perbedaan antara Fatwa, Qanun, Qadha dan Ijtihad. https://www.rumahfiqih.com/konsultasi-2132-perbedaan-antara-fatwa-qanun-qadha-danijtihad.html

Syafi'i, A. (2001). Bank Syariah: Dari Teori Ke Praktek (Cet. 1). Gema Insani Press.

Tarmizi, E. (2017). Harta Haram Muamalat Kontemporer. BMI Publishing. 
Tausikal, M. A. (2009). Riba dalam Emas. https://rumaysho.com/364-riba-dalam-emas-dll-ribafadhl.html 